Postgraduate Bosowa University Publishing (PBUP)
Indonesian Journal of Business and Management
e-ISSN: $2460-3767 \quad p$-ISSN: $2656-6885$
INttps://postgraduate.universitasbosowa
JOURAL

\title{
PENGARUH KEPEMIMPINAN, BUDAYA ORGANISASI DAN DISIPLIN KERJA TERHADAP KINERJA PEGAWAI PADA DINAS KESEJAHTERAAN SOSIAL KABUPATEN DEIYAI PROVINSI PAPUA
}

\author{
The Influence of Leadership, Organizational Culture and Work Discipline on the Employee \\ Performance at the Social Welfare Department of Deiyai Regency, Papua Province \\ Robert Edowai ${ }^{1}$, Herminawati Abubakar ${ }^{2}$, Arifuddin Mane $^{2}$ \\ ${ }^{1}$ Dinas Kesejahteraan Sosial Kabupaten Deiyai Provinsi Papua \\ ${ }^{2}$ Program Studi Manajemen Program Pascasarjana Universitas Bosowa \\ Email: robertedowai@gmail.com
}

Diterima: 13 Februari 2020 /Disetujui: 05 Juni 2020

\begin{abstract}
ABSTRAK
Sumber Daya Manusia (pegawai) merupakan unsur yang strategis dalam menentukan sehat tidaknya suatu organisasi. Pengembangan SDM yang terencana dan berkelanjutan merupakan kebutuhan yang mutlak terutama untuk masa depan organisasi. Tujuan penelitian ini adalah untuk mengetahui dan menganalisis pengaruh kepemimpinan, budaya organisasi, dan disiplin kerja terhadap kinerja pengawai pada Dinas Kesejahteraan Sosial Kabupaten Deiyai Kabupaten Papua. Teknik pengumpulan data dalam penelitian ini dalam bentuk penyabaran kuesioner. Kemudian jumlah sampel ditetapkan sebanyak 35 orang. Pengujian hipotesis dilakukan dengan menggunakan analisis linier Berganda dan untuk menjelaskan hubungan variabel yang dianalisis menggunakan uji statistik program SPSS 23.0 for windows. Berdasarkan hasil penelitian dapat diketahui bahwa kepemimpinan mempunyai pengaruh positif dan signifikan terhadap kinerja pegawai. Budaya organisasi berpengaruh positif dan signifikan terhadap terhadap kinerja pegawai. Disiplin kerja mempunyai pengaruh positif dan signifikan terhadap kinerja pegawai Dinas Kesejahteraan Sosial Kabupaten Deiyai Provinsi Papua. Berdasarkan hasil uji serempak diperoleh hasil bahwa kepemimpinan, budaya organisasi dan disiplin kerja mempunyai pengaruh secara serempak atau bersama-sama terhadap kinerja pegawai pada Dinas Kesejahteraan Sosial Kabupaten Deiyai Provinsi Papua.
\end{abstract}

Kata Kunci : Kepemimpinan, Budaya Organisasi, Disiplin Kerja, dan Kinerja Pegawai

\begin{abstract}
Human Resources (employees) are a strategic element in determining whether an organization is healthy or not. Planned and sustainable HR development is an absolutenecessity especially for the future of the organization. The purpose of this study was to determine and analyze the influence of leadership, organizational culture, and work discipline on the performance of employees in the Social Welfare Office of Deiyai Regency, Papua Regency. Data collection techniques in this study were in the form of questionnaires. Then, the number of samples was set at 35 people. Hypothesis testing is carried out using Multiple linear analysis and to explain the relationship of variables, the analysis uses the statistical test program SPSS 23.0 for windows. Based on the research results, it can be seen that leadership has a positive and significant influence on the employee performance. Organizational culture has a positive and significant effect on the employee performance. Work discipline has a positive and significant effect on the performance of employees of the Social Welfare Office of Deiyai Regency, Papua Province. Based on the simultaneous test results obtained that leadership, organizational culture and work discipline have an influence simultaneously or jointly on the performance of employees at the Social Welfare Office of Deiyai Regency, Papua Province.
\end{abstract}

Keywords: Leadership, Organizational Culture, Work Discipline, Employee Performance 


\section{PENDAHULUAN}

Organisasi merupakan suatu sistem yang saling mempengaruhi satu sama lain, apabila salah satu dari sub sistem tersebut rusak, maka akan mempengaruhi sub-sub sistem yang lain (Al Fatta, 2007; Jamaluddin et. al., 2017; Saggaf et. al., 2014; Tadampali et. al., 2016; Toha, 2014). Sistem tersebut dapat berjalan dengan semestinya jika individu-individu yang ada di dalamnya berkewajiban mengaturnya, yang berarti selama anggota atau individunya masih suka dan melaksanakan tanggungjawab sebagaimana mestinya maka organisasi tersebut akan berjalan dengan baik. Sumber Daya Manusia (SDM) merupakan unsur yang strategis dalam menentukan sehat tidaknya suatu organisasi. Pengembangan SDM yang terencana dan berkelanjutan merupakan kebutuhan yang mutlak terutama untuk masa depan organisasi.

Sumber Daya Manusia (pegawai) merupakan unsur yang strategis dalam menentukan sehat tidaknya suatu organisasi. Sumber daya yang menggerakkan dan mengarahkan organisasi, sumber daya manusia harus selalu diperhatikan, dijaga, dipertahankan serta dikembangkan oleh organisasi (Pfeffer \& Salancik, 2003). Manajemen Sumber Daya Manusia merupakan faktor yang sangat penting dalam sebuah organisasi dengan skala besar maupun kecil, sumber daya manusia dipandang sebagai unsur yang sangat menentukan dalam proses pengembangan organisasi karena pengembangan kualitas pelayanan akan terealisasi apabila ditunjang oleh sumber daya manusia yang berkualitas (Tangkilisan, 2005)

Pengembangan SDM yang terencana dan berkelanjutan merupakan kebutuhan yang mutlak terutama untuk masa depan organisasi. Dalam kondisi lingkungan tersebut, manajemen dituntut untuk mengembangkan cara baru untuk mempertahankan pegawai pada produktifitas tinggi serta mengembangkan potensinya agar memberikan kontribusi maksimal pada organisasi. Masalah sumber daya manusia yang kelihatannya hanya merupakan masalah intern dari suatu organisasi sesungguhnya mempunyai hubungan yang erat dengan masyarakat luas sebagai pelayanan publik yang diukur dari kinerja.

Manajemen sumber daya manusia merupakan sarana untuk meningkatkan kualitas manusia, dengan memperbaiki sumber daya manusia, meningkatkan pula kinerja dan daya hasil organisasi, sehingga dapat mewujudkan pegawai yang memiliki kepemimpinan,budaya organisasi serta disiplin kerja akan berpengaruh kepada kinerja yang tinggi sehingga diperlukan pula peran yang besar dari pimpinan organisasi. Dalam meningkatkan kinerja pegawai diperlukan analisis terhadap faktor-faktor yang mempengaruhinya dengan memperhatikan kebutuhan dari para pegawai, diantaranya adalah terbentuknya budaya organisasi, kepemimpinan yang baik dan terkoordinasi di semua sektor. Kemampuan seorang pemimpin adalah memotivasi, mempengaruhi, mengarahkan dan berkomunikasi dengan bawahannya (Lubis, 2008). Proses memotivasi sangat tergantung pada kemampuan pemimpin dalam mempengaruhi bawahannya dalam upaya untuk mewujudkan tujuan organisasi (Kencanawati, 2013; Edowai et al., 2020). Keberhasilan atau kegagalan yang dialami sebagian besar organisasi ditentukan oleh kualitas kepemimpinan yang dimiliki oleh orang-orang yang diserahi tugas memimpin organisasi tersebut. Disamping itu, pemimpin juga harus mempunyai perilaku atau cara kepemimpinan yang disesuaikan dengan situasi dan kondisi organisasi, bersifat fleksibel artinya mampu menyesuaikan atau beradaptasi dengan lingkungan bawahannya. Selain itu, budaya organisasi dan disiplin kerja merupakan faktor penentu berhasil tidaknya suatu organisasi dalam mencapai tujuan organisasi sebagaimana diharapkan termasuk tercpainya kinerja pegawai yang baik.

Banyak faktor yang mempengaruhi kinerja pegawai, antara lain faktor kepuasan kerja, faktor komunikasi, faktor pengalaman kerja, faktor kedisiplinan, faktor kepemimpinan, faktor kompetensi, faktor budaya organisasi dan faktor lingkungan kerja. Namun menurut observasi yang dilakukan peneliti berbagai hal permasalahan tersebut ditemukan di lokasi penelitian yaitu di Dinas Kesejahteraan Sosial Kabupaten Deiyai. Penomena yang ditemukan adalah Sebagian pegawai menunjukkan disiplin kerja rendah dilihat dari absensi, pegawai yang tidak mengikuti apel di Dinas Kesejahteraan Sosial Kabupaten Deiyai, pegawai datang terlambat, masih adanya pegawai yang pulang lebih cepat, dari observasi dan informasi yang didapatkan dari kepala Sub Bagian Kepegawaian masih ditemukan pegawai tidak mengisi absensi sesuai yang seharusnya, masih adanya pegawai yang suka duduk santai pada jam kerja, sambil bergosip dan semangat untuk menjalankan aktivitas masih rendah, adanya gaya kepemimpinan yang kurang tegas, tidak adanya sanksi yang tegas, keluhan pegawai yang sangat tinggi pada akhirnya kehadiran yang sangat kurang pengaruh budaya yang masih saja dibawah ke pemerintahan dan hal itu menunjukkan masih rendahnya kinerja sebagian pegawai terhadap Dinas Kesejahteraan Sosial Kabupaten Deiyai.

\section{METODE}

\subsection{Jenis Penelitian}

Rancangan penelitian yang digunakan adalah desain deskriptif analitik kuantitatif yang bertujuan menguraikan sifat dan karakteristik data-data atau variabel yang akan diujikan. Selain itu, desain penelitian ini digunakan untuk mendeskripsikan dan menggambarkan apa adanya mengenai suatu variabel, gejala, keadaan, atau fenomena tertentu, sehingga dalam penelitian ini digunakan untuk menganalisis data yang diperoleh secara mendalam dengan harapan dapat diketahuinya pengaruh antara variabel bebas terhadap variabel terikat. Dalam hal ini variabel yang akan diuji adalah variabel bebas pertama (X1) Kepemimpinan, variabel bebas kedua (X2) budaya organisasi, variabel bebas ketiga (X3) disiplin kerja, dan 
variabel terikat $(\mathrm{Y})$ kinerja karyawan. Penelitian ini juga mengunakan desain kausal yang bertujuan untuk menganalisa hubungan atau tingkat pengaruh variabel bebas terhadap bariabel terikat, apakah hubungan cukup signifikan melalui uj regresi.

\subsection{Lokasi Penelitian}

Penelitian ini dilaksanakan di Dinas Kesejahteraan Sosial Kabupaten Deiyai, yang beralamat di Jl. Trans Waghete, Kecamatan Tigi Kabupaten Deiyai Provinsi Papua.

\subsection{Populasi dan Sampel}

Sekaran (2017) mengemukakan populasi mengacu pada keseluruhan orang, kejadian atau hal-hal yang menarik yang ingin peneliti investigasi. Populasi dalam penelitian ini adalah seluruh pegawai Dinas Kesejahteraan Sosial Kabupaten Deiyai Provinsi Papua sebanyak 35 orang. Sampel adalah sebagian dari populasi, sampel terdiri atas sejumlah anggota yang dipilih dari populasi. Penetapan sampel dalam penelitian ini menggunakan metode sensus (sampel jenuh) karena jumlah populasi relative sedikit maka semua populasi dianggap sebagai sampel sebanyak 35 orang.

\subsection{Variabel Penelitian}

Variabel dalam penelitian ini terbagi atas variabel bebas (dependen variabel) dan variabel terikat (independen variabel). Variabel bebas disebut juga variabel $\mathrm{X}$ yang terdiri atas kepemimpinan (X1), budaya organisasi (X2), disiplin kerja (X3) dan variabel terikat disebut juga variabel $\mathrm{Y}$, yaitu kinerja organisasi.

\subsection{Teknik Pengumpulan Data}

Pada penelitian ini, data diperoleh melalui jawaban responden atas kuesioner yang dibagikan kepada sampel dalam penelitian ini, selain itu data dapat juga diperoleh melalui catatan dan arsip yang disediakan oleh Dinas Kesejahteraan sosial Kabupaten Deiyai Provinsi Papua.

\subsection{Jenis dan Sumber Data}

Data yang digunakan dalam penelitian, terbagi atas data primer merupakan data yang diperoleh secara langsung oleh peneliti melalui jawaban responden terhadap kuesioner mengenai pengaruh kepemimpinan, budaya organisasi dan disiplin kerja terhadap kinerja pegawai di Dinas Kesejahteraan Sosial Kabupaten Deiyai Provinsi Papua, serta b. Data Sekunder, data yang diperoleh secara tidak langsung melalui sumberr lain, seperti catatan, arsip dinas kesejahteraan sosial dan data sekunder berupa publikasi ilmiah.

\subsection{Analisis Data}

Analisa kuantitatif adalah metode analisis data yang memerlukan perhitungan statistik. Untuk mempermudah dalam melakukan analisis data digunakan analisis regresi linear berganda dengan program SPSS 23. Adapun alat analisis yang digunakan dalam penelitian ini adalah sebagai berikut:

a. Analisis Deskriptif berupa analisa data yang akan dilakukan berupa analisa deskriptif dalam frekuensi berbentuk persentase $(\%)$, sehingga data menjadi mudah diinterpretasikan. Proses pengolahan data dan analisa data menggunakan apliksi program SPSS 23.

b. Uji Asumsi Klasik berupaL

1) Uji Normalitas

Uji normalitas bertujuan untuk menguji apakah dalam model regresi, variabel terikat dan variabel bebas mempunyai distribusi normal atau tidak. Normalitas dapat diuji dengan menggunakan uji Kolmogorov-Smirnov, yang dapat dilakukan dengan menggunakan SPSS.

2) Uji Linieritas

Uji linearitas bertujuan untuk mengetahui apakah dua variabel mempunyai hubungan yang linear atau tidak secara signifikan. Uji ini biasanya digunakan sebagai prasyarat dalam analisis korelasi atau regresi linear. Pengujian pada SPSS dengan menggunakan Test for Linearity dengan pada taraf signifikansi 0,05 . Dua variabel dikatakan mempunyai hubungan yang linear bila signifikansi (linearity) kurang dari 0,05.

3) Uji multikolineritas

Uji multikolineritas bertujuan untuk menguji apakah model regresi ditemukan adanya korelasi atas variabel bebas (independen). Model regresi yang baik seharusnya bebas multikolineritas atau tidak terjadi korelasi diantara variabel independen. Uji Multikolineritas dapat dilihat dari (1) nilai tolerance dan lawannya (2) Variance Inflation Factor (VIF).

4) Uji Heterokesdastisitas

Bertujuan menguji apakah dalam model regresi terjadi ketidaksamaan variance dari residual suatu pengamatan ke pengamatan yang lain tetap, maka disebut homokedaskisitas, dan jika berbeda disebut Heterokesdastisitas Gozali, (2018). Model regresi yang baik adalah tidak terjadi heterokesdastisitas.

c. Analisa Kausal berupa uji regresi yang digunakan dalam penelitian ini menggunakan analisa regresi linier berganda. Teknis analisa yang akan digunakan dengan uji partial dengan (t-test) untuk mengetahui seberapa jauh pengaruh masing masing variabel bebas terhadap variabel terikat.

Melalui software SPSS 23 akan diketahui koefisien regresi dari masing-masing variabel bebas. Selanjutnya dapat disusun persamaan regresi berganda:

$$
\begin{aligned}
& \mathrm{Y}=\beta 0+\beta 1 \mathrm{X} 1+\beta 2 \mathrm{X} 2+\beta 3 \mathrm{X} 3+\mathrm{e} \\
& \text { dimana: } \\
& \mathrm{Y} \quad=\text { Kinerja karyawan } \\
& \beta 0-\beta 3=\text { Koefisien regresi } \\
& \mathrm{X} 1 \quad=\text { Kepemimpinan } \\
& \mathrm{X} 2 \quad=\text { Budaya Organisasi } \\
& \mathrm{X} 3 \quad=\text { Disiplin kerja } \\
& \mathrm{E} \quad=\text { Standar error }
\end{aligned}
$$$$
\text { Standar error }
$$ 
d. Uji Hipotesis

1) Uji T (Uji parsial)

Uji ini adalah untuk mengetahui apakah pengaruh masing-masing variabel bebas terhadap variabel terikat bermakna atau tidak, pengujian ini dilakukan dengan membandingkan antara nilai thitung masing-masing variabel bebas dengan nilai ttabel dengan derajat kesalahan $5 \%$ $(\alpha=0.05)$. Apabila nilai thitung $\geq$ ttabel, maka variabel bebasnya memberikan pengaruh bermakna terhadap variabel terikat.

2) Uji F (Uji serempak)

Uji ini digunakan untuk mengetahui apakah seluruh variabel bebasnya secara bersama-sama mempunyai pengaruh yang bermakna terhadap variabel terikat. Pengujian dilakukan dengan membandingkan nilai Fhitung dengan Ftabel pada derajat kesalahan $5 \%(\alpha=0.05)$. Apabila nilai Fhitung $\geq$ dari nilai Ftabel, maka berarti variabel bebasnya secara bersamasama memberikan pengaruh yang bermakna terhadap variabel terikat. Dengan menggunakan alat bantu program SPSS versi 23.

3) Uji Koefisien Determinasi (R2)

Uji koefisien determinasi pada intinya mengukur seberapa jauh kemampuan model dalam menerangkan variasi variabel independen. Nilai koefisien determinasi adalah antara nol dan satu. Nilai R2 yang kecil berarti kemampuan variabel-variabel independen dalam menjelaskan variasi variabel dependen sangat terbatas. Nilai yang mendekati satu berarti variabel-variabel independen memberikan hampir semua informasi yang dibutuhkan untuk memprediksi variasi variabel dependen Ghozali, (2018:87).

\section{HASIL DAN PEMBAHASAN}

Setiap individu selalu mempunyai sifat yang berbeda satu dengan yang lainnya. Sifat tersebut dapat menjadi ciri khas bagi seseorang sehingga kita dapat mengetahui bagaimana sifatnya. Sama halnya dengan manusia, organisasi juga mempunyai sifat-sifat tertentu. Melalui sifat-sifat tersebut kita juga dapat mengetahui bagaimana karakter dari organisasi tersebut. Sifat tersebut kita kenal dengan budaya organisasi. Budayabudaya yang dimiliki oleh setiap suku bangsa memiliki sistem nilai dan norma dalam mengatur masing-masing anggotanya dari suku bangsa tersebut maupun orang yang berasal dari suku lain, dengan demikian dapat dikatakan bahwa suatu organisasi juga memiliki budaya yang mengatur bagaimana anggota-anggotanya untuk bertindak. Budaya memberikan identitas bagi para anggota organisasi dan membangkitkan komitmen terhadap keyakinan dan nilai yang lebih besar dari dirinya sendiri (Mathis, 2011). Meskipun ideide ini telah menjadi bagian budaya itu sendiri yangbisa datang di manapun organisasi itu berada. Suatu organisasi budaya berfungsi untuk menghubungkan para anggotanya sehingga mereka tahu bagaimana berinteraksi satu sama lain.

Budaya organisasi merupakan sebagai suatu pola dari asumsi-asumsi dasar yang ditemukan, diciptakan atau dikembangkan oleh suatu kelompok tertentu dengan maksud agar organisasi bisa mengatasi, menanggulangi permasalahan yang timbul akibat adaptasi eksternal dan integritas internal yang sudah berjalan dengan cukup baik sehingga perlu diajarkan dan diterapkan kepada anggotaanggota baru sebagai cara yang benar untuk memahami, memikirkan dan merasakan berteman dengan merekamereka tersebut. Setiap individu yang tergabung di dalam sebuah organisasi memiliki budaya yang berbeda, disebabkan mereka memiliki latar belakang budaya yang berbeda, namun semua perbedaan itu akan dilebur menjadi satu di dalam sebuah budaya yaitu budaya organisasi, untuk menjadi sebuah kelompok yang bekerjasama dalam mencapai tujuan organisasi sebagaimana yang telah disepakati bersama sebelumnya, tetapi dalam proses tersebut tidak tertutup kemungkinan ada individu yang bisa menerima dan juga yang tidak bisa menerimanya, yang mungkin bertentangan dengan budaya yang dimilikinya. Disiplin kerja merupakan bentuk ketaatan dari perilaku seseorang dalam mematuhi ketentuanketentuan ataupun peraturan-peraturan tertentu yang berkaitan dengan pekerjaan dan diberlakukan dalam suatu organisasi (Wijaya, 2013). Disiplin kerja perlu dimiliki oleh setiap orang agar kehidupan organisasi bisa aman, tertib dan lancar. Hilangnya disiplin kerja akan berpengaruh terhadap efisiensi kerja dan efektivitas tugas pekerjaan yang jika kedisiplinan tidak ditegakkan maka kemungkinan tujuan yang ditetapkan tidak akan dapat dicapai secara efektif dan efisien. Sebagai gambaran apabila suatu perusahaan hanya memperhatikan tentang pendidikan, keahlian dan teknologi tanpa memikirkan disiplin kerja pegawai, maka pendidikan, keahlian dan teknologi yang tinggi sekalipun tidak akan menghasilkan produk yang maksimal bila yang bersangkutan tidak dapat memanfaatkannya secara teratur dan mempunyai kesungguhan disiplin kerja yang tinggi.

Suatu instansi didirikan karena mempunyai tujuan yang ingin dicapai. Dalam mencapai tujuannya setiap instansi dipengaruhi oleh perilaku dan sikap orang-orang yang terdapat dalam instansi tersebut. Keberhasilan untuk mencapai tujuan tersebut tergantung kepada keandalan dan kemampuan pegawai dalam mengoperasikan unit-unit kerja yang terdapat di instansi tersebut, karena tujuan instansi dapat tercapai hanya dimungkinkan karena upaya para pelaku yang terdapat dalam setiap instansi. Kinerja pegawai merupakan salah satu tolok ukur dari kinerja organisasi, sehingga dalam hal ini perlu selalu mengevaluasi prestasi kerja tersebut dalam rangka untuk mempertahankan atau meningkatkan kinerja organisasi dan sebaliknya prestasi kerja yang sudah baik harus dipertahankan atau bahkan selalu ditingkatkan.

Pegawai Dinas Kesejahteraan Sosial Kabupaten Deiyai adalah aset yang paling penting yang harus dimiliki oleh Pemerintah. Arti penting manusia bermuara 
dari kenyataan bahwa orang-orang (manusia) merupakan elemen yang senantiasa ada di dalam organisasi. Manusia membuat tujuan, mengadakan inovasi, dan mencapai tujuan organisasi. Sumber daya manusia memicu kreatifitas di setiap organisasi. Tanpa adanya sumber daya manusia yang efektif akan mustahil bagi organisasi untuk mencapai tujuannya. Sumber daya manusia membuat sumber daya organisasi lainnya berjalan..

Jumlah pegawai yang besar tersebut merupakan salah satu potensi yang besar bagi Dinas Kesejahteraan Sosial Kabupaten Deiyai. Peningkatan hasil produksi yang berkelanjutan menuntut adanya Sumber Daya Manusia (SDM) yang berkinerja tinggi. Pegawai yang memiliki sikap pengabdian, disiplin dan kemampuan profesional sangat mungkin mempunyai prestasi kerja dalam melaksanakan tugas sehingga lebih berdaya guna dan berhasil guna. Pegawai yang profesional dapat diartikan sebagai sebuah pandangan untuk selalu perpikir, kerja keras, bekerja sepenuh waktu, disiplin, jujur, loyalitas tinggi, dan penuh dedikasi demi untuk keberhasilan pekerjaannya. Untuk mencapai hasil produksi yang tinggi pimpinan perusahaan harus memperhatikan disiplin kerja.

Untuk mengetahui bagaimana pengaruh kepemimpinan, budaya organisasi dan disiplin kerja terhadap kinerja pegawai dapat dilihat dengan menggunakan analisis regresi linier berganda, sehingga diperoleh persamaan :

$\mathrm{Y}=\mathrm{bo}+\mathrm{b} 1 \mathrm{X} 1+\mathrm{b} 2 \mathrm{X} 2+\mathrm{b} 3 \mathrm{X} 3$.

atau persamaan :

$Y=-2,763+0,410 X 1+0,444 X 2+0,273 X 3 \ldots \ldots . .(3)$

Hasil persamaan regresi tersebut maka dapat diinterprestasikan atau diberikan penjelasan sebagai berikut :

1) Nilai konstanta (bo) sebesar -2,763. Artinya adalah apabila kepemimpinan, budaya organisasi dan disiplin kerja diasumsikan nol (0), maka kinerja pegawai bernilai $-2,763$.

2) Nilai koefisien regresi variabel kepemimpinan sebesar 0,410 yang artinya adalah bahwa setiap peningkatan kepemimpinan sebesar satu (1) satuan maka akan meningkatkan nilai kinerja pegawai sebesar 0,410 dengan asumsi variabel lain tetap.

3) Nilai koefisien regresi variabel budaya organisasi sebesar 0,444 yang artinya adalah bahwa setiap peningkatan budaya organisasi sebesar satu (1) satuan maka akan meningkatkan nilai kinerja pegawai sebesar 0,444 dengan asumsi variabel lain tetap.

4) Nilai koefisien regresi variabel disiplin kerja 0,273 yang artinya adalah bahwa setiap peningkatan stres kerja sebesar satu (1) satuan maka akan meningkatkan nilai kinerja pegawai sebesar 0,273 dengan asumsi variabel lain tetap. Koefisien Determinasi (R2)
Uji koefisien determinasi dilakukan untuk mengetahui persentase sumbangan pengaruh variabel independen secara serentak terhadap variabel dependen. Koefisien ini menunjukkan seberapa besar persentase variasi variabel independen yang digunakan dalam model mampu menjelaskan variasi variabel dependen. Uji Koefisien determinasi dalam penelitian ini dapat dilihat pada tabel berikut :

Tabel 1 Hasil Uji Koefisien Determinasi

\begin{tabular}{lcccc}
\hline Model & $\mathrm{R}$ & $\begin{array}{c}\mathrm{R} \\
\text { Square }\end{array}$ & $\begin{array}{c}\text { Adjusted } \mathrm{R} \\
\text { Square }\end{array}$ & $\begin{array}{c}\text { Std. Error of the } \\
\text { Estimate }\end{array}$ \\
\hline 1 & $.801^{\mathrm{a}}$ & .642 & .607 & 3.46957 \\
\hline $\begin{array}{l}\text { a. Predictors: } \\
\text { Organisasi }\end{array}$ \\
$\begin{array}{l}\text { Sumber : Data diolah, } 2020 \\
\text { Sumstant), }\end{array}$ & Disiplin & Kerja, & Kepemimpinan, Budaya \\
\end{tabular}

Hasil olahan data diketahui nilai R Square sebesar 0,642, artinya adalah bahwa sumbangan pengaruh variabel independen (kepemimpinan, budaya organisasi dan disiplin kerja) terhadap variabel dependen (kinerja pegawai) adalah sebesar 64,2\%, sedangkan sisanya sebesar $35,8 \%$ dipengaruhi oleh variabel lain yang tidak dimasukkan dalam model ini.

Uji-t dilakukan untuk menguji pengaruh secara signifikan independen yaitu (X1 dan X2) berupa variabel kepemimpinan, budaya organisasi dan disiplin kerja terhadap kinerja pegawai Dinas Kesejahteraan Sosial Kabupaten Deiyai Provinsi Papua, dimana dapat dilakukan dengan membandingkan antara nilai signifikan dengan nilai standar. Dari hasil pengujian regresi maka dapat dijelaskan hasil pengujian parsial sebagai berikut :

1) Nilai signifikan variabel kepemimpinan adalah $0,007<$ lebih kecil dari nilai standar 0,05, sehingga dapat disimpulkan bahwa variabel kepemimpinan berpengaruh signifikan terhadap kinerja pegawai Dinas Kesejahteraan Sosial Kabupaten Deiyai Provinsi Papua.

2) Nilai signifikan variabel budaya organisasi adalah $0,001<$ lebih kecil dari nilai standar 0,05, sehingga dapat disimpulkan bahwa variabel budaya organisasi berpengaruh signifikan terhadap kinerja pegawai Dinas Kesejahteraan Sosial Kabupaten Deiyai Provinsi Papua.

3) Nilai signifikan disiplin kerja adalah 0,030 dan nilai standar 0,05, karena nilai signifikan $0,030<0,05$, sehingga dapat disimpulkan bahwa variabel disiplin kerja berpengaruh signifikan terhadap kinerja pegawai Dinas Kesejahteraan Sosial Kabupaten Deiyai Provinsi Papua.

Uji F (uji serempak) dilakukan untuk melihat pengaruh secara bersama-sama (serentak) dari variabel independen yaitu (X1, X2, X3) berupa variabel kepemimpinan, budaya organisasi dan disiplin kerja terhadap kinerja pegawai Dinas Kesejahteraan Sosial Kabupaten Deiyai Provinsi Papua. Adapun cara pengujiannya yakni dengan membandingkan antara 
nilai signifikan dan nilai standar. Untuk lebih jelasnya hasil uji simultan dapat disajikan melalui tabel berikut ini.

Tabel 2 Hasil Uji Serempak (Uji F)

\begin{tabular}{lcrlll}
\hline \multicolumn{1}{c}{ Model } & $\begin{array}{l}\text { Sum of } \\
\text { Squares }\end{array}$ & Df & $\begin{array}{l}\text { Mean } \\
\text { Square }\end{array}$ & F & Sig. \\
\hline Regression & 668.368 & 3 & 222.789 & 18.507 & $.000^{\mathrm{b}}$ \\
\hline Residual & 373.175 & 31 & 12.038 & & \\
\hline Total & 1041.543 & 34 & & & \\
\hline Sumber: Hasil SPSS & & & &
\end{tabular}

Berdasarkan Tabel 2 di atas maka diperoleh nilai signifikan sebesar 0,000 , karena nilai signifikan $0,000<$ 0,05 , hal ini menunjukkan bahwa kepemimpinan, budaya organisasi, dan disiplin kerja mempunyai pengaruh secara bersama-sama terhadap terhadap kinerja pegawai Dinas Kesejahteraan Sosial Kabupaten Deiyai Provinsi Papua.

Pengaruh Kepemimpinan Terhadap Kinerja Pegawai

Hasil analisis dalam penelitian ini, dapat diketahui bahwa variabel disiplin kerja berpengaruh terhadap kinerja pegawai Dinas Kesejahteraan Sosial Kabupaten Deiyai Provinsi Papua, hal ini dibuktikan dengan nilai $t$ hitung sebesar 3,658 dengan taraf signifikansi hasil sebesar 0,007 tersebut lebih kecil dari 0,05, dengan demikian Ha diterima dan Ho ditolak. Pengujian ini secara statistik membuktikan bahwa kepemimpinan berpengaruh positif dan signifikan terhadap kinerja pegawai. Artinya bahwa ada pengaruh antara kepemimpinan terhadap kinerja pegawai pada Dinas Kesejahteraan Sosial Kabupaten Deiyai Provinsi Papua.

Kemudian berdasarkan hasil kuesioner yang peneliti sebarkan kepada pegawai Dinas Kesejahteraan Sosial Kabupaten Deiyai Provinsi Papua diketahui bahwa variabel kepemimpinan ditanggapi sudah baik atau tinggi oleh pegawai. Dimana menurut score tertinggi pada pernyataan pemimpin mengikut sertakan pegawai dalam merumuskan pelaksanaan kerja dan pernyataan pemimpin memberikan kepercayaan penuh pada bawahannya dalam pelaksanaan pekerjaan.

Pengaruh Budaya Orgaisasi Terhadap Kinerja Pegawai

Hasil analisis dalam penelitian ini, dapat diketahui bahwa variabel budaya organisasi berpengaruh terhadap kinerja pegawai Dinas Kesejahteraan Sosial Kabupaten Deiyai Provinsi Papua, hal ini dibuktikan dengan nilai $t$ hitung sebesar 3,658 dengan taraf signifikansi hasil sebesar 0,001 tersebut lebih kecil dari 0,05, dengan demikian Ha diterima dan Ho ditolak. Pengujian ini secara statistik membuktikan bahwa budaya organisasi berpengaruh positif dan signifikan terhadap kinerja pegawai. Artinya bahwa ada pengaruh antara budaya organisasi terhadap kinerja pegawai pada Dinas Kesejahteraan Sosial Kabupaten Deiyai Provinsi Papua. Kemudian berdasarkan hasil kuesioner yang peneliti sebarkan kepada pegawai Dinas Kesejahteraan Sosial Kabupaten Deiyai Provinsi Papua diketahui bahwa variabel budaya organisasi ditanggapi sudah baik atau tinggi oleh pegawai. Dimana menurut score tertinggi ada pada pernyataan pegawai selalu dituntut untuk menyelesaikan pekerjaan dengan tepat dan cermat dan pernyataan pegawai dituntut untuk bekerja giat dalam melakukan pekerjaan yang menjadi tanggung jawab pegawai..

\section{Pengaruh Disiplin Kerja Terhadap Kinerja Pegawai}

Hasil analisis dalam penelitian ini, dapat diketahui bahwa variabel disiplin kerja berpengaruh terhadap kinerja pegawai Dinas Kesejahteraan Sosial Kabupaten Deiyai Provinsi Papua, hal ini dibuktikan dengan nilai $\mathrm{t}$ hitung sebesar 2,278 dengan taraf signifikansi hasil sebesar 0,030 tersebut lebih kecil dari 0,05, dengan demikian Ha diterima dan Ho ditolak. Pengujian ini secara statistik membuktikan bahwa disiplin kerja berpengaruh positif dan signifikan terhadap kinerja pegawai. Artinya bahwa ada pengaruh antara disiplin kerja terhadap kinerja pegawai pada Dinas Kesejahteraan Sosial Kabupaten Deiyai Provinsi Papua. Kemudian berdasarkan hasil kuesioner yang peneliti sebarkan kepada pegawai Dinas Kesejahteraan Sosial Kabupaten Deiyai Provinsi Papua diketahui bahwa variabel disiplin kerja ditanggapi sudah baik atau tinggi oleh pegawai. Dimana menurut score tertinggi ada pada pernyataan pegawai yang tidak beretika baik semestinya mendapatkan sanksi.

\section{SIMPULAN}

Simpulan dalam penelitian ini bahwa kepemimpinan mempunyai pengaruh positif terhadap kinerja pegawai. budaya organisasi pegawai Dinas Kesejahteraan Sosial Kabupaten Deiyai Provinsi Papua. Berdasarkan hasil uji serempak diperoleh hasil bahwa kepemimpinan, budaya organisasi dan disiplin kerja mempunyai pengaruh secara serempak atau bersama-sama terhadap kinerja pegawai pada Dinas Kesejahteraan Sosial Kabupaten Deiyai Provinsi Papua.

\section{DAFTAR PUSTAKA}

Al Fatta, H. (2007). Analisis dan Perancangan Sistem Informasi untuk keunggulan bersaing perusahaan dan organisasi modern. Penerbit Andi.

Edowai, Y., Mardjuni, S., \& Saleh, M. Y. (2020). Pengaruh Motivasi, Disiplin Kerja Dan Kepemimpinan Terhadap Kinerja Pegawai Dinas Kesehatan Kabupaten Deiyai Propinsi Papua. Indonesian Journal of Business and Management, 2(1), 41-46.

Ghozali, Imam. (2018). Aplikasi Analisis Multivariate dengan Program SPSS. Semarang: UNDIP.

Jamaluddin, J., Salam, R., Yunus, H., \& Akib, H. (2017). Pengaruh Budaya Organisasi terhadap Kinerja Pegawai pada Dinas Pendidikan Provinsi Sulawesi Selatan. Jurnal Ad'ministrare, 4(1), 25-34

Kencanawati. A. A. A. M. (2013). Kepemimpinan, Etos Kerja, Motivasi, dan Disiplin Terhadap Kinerja Pegawai Kantor Pelayanan Pajak Madya Denpasar Jurnal Bisnis dan Kewirausahaan.

Lubis K. A. (2008). Pengaruh Pelatihan dan Motivasi Kerja Terhadap Kinerja Karyawan PT Perkebunan Nusantara IV (Persero) Medan. Tesis. USU. 
Mathis, R. L, Jackson, J. H. (2011). Human Resource Management: Manajemen Sumber Daya Manusia. Edisi 10. Jakarta: Salemba Empat.

Pfeffer, J., \& Salancik, G. R. (2003). The external control of organizations: A resource dependence perspective. Stanford University Press.

Saggaf, S., Salam, R., Kahar, F., \& Akib, H. (2014). Pelayanan Fungsi Administrasi Perkantoran Modern. Jurnal Ad'ministrare, 1(1), 20-27.

Sekaran, Uma dan Roger Bougie. (2017). Metode Penelitian untuk Bisnis: Pendekatan Pengembangan Keahlian. Edisi Keenam. Buku satu, Cetakan Kedua, Penerbit : Salemba Empat, Jakarta Selatan.

Tadampali, A. C. T., Hadi, A., \& Salam, R. (2016). Pengaruh Iklim Organisasi terhadap Turnover Intention Melalui Kepuasan Kerja sebagai Variabel Intervening pada PT Bank SulSelBar. Jurnal Ilmiah Ilmu Administrasi Publik, 6(2), 35-46.

Tangkilisan, H. N. S. (2005). Manajemen publik. Grasindo.

Thoha, Miftah. 2014. Perilaku Organisasi : Konsep Dasar dan Aplikasinya, cetakan ke-23. Jakarta : Rajawali Pers.

Wijaya, Tony. 2013. Metodologi Penelitian, Ekonomi dan Bisnis, Teori dan Praktik. Yogyakarta: Graha Ilmu. 